\title{
Response of growing chicks to supplementation of low protein diets with leucine, valine and glycine-glutamic acid
}

\author{
SH. Golzar Adabi ${ }^{1,2 \#}$, N. Ceylan ${ }^{1}$, I. Çiftci ${ }^{1}$ \& A. Ceylan ${ }^{3}$ \\ ${ }^{1}$ Department of Animal Science, Feeds and Animal Nutrition, Faculty of Agriculture, Ankara University, Ankara, 06110, \\ Turkey \\ ${ }^{2}$ Huvepharma, Istanbul, Turkey, 34870 \\ ${ }^{3}$ Department of Histology \& Embryology, Faculty of Veterinary Medicine, Ankara University, Ankara, Turkey
}

(Received 20 March 2019; Accepted 21 November 2019; First published online 19 January 2020)

\author{
Copyright resides with the authors in terms of the Creative Commons Attribution 4.0 South African Licence. \\ See: http://creativecommons.org/licenses/by/4.0/za \\ Condition of use: The user may copy, distribute, transmit and adapt the work, but must recognise the authors and the South African \\ Journal of Animal Science.
}

\begin{abstract}
This experiment was conducted to determine the interaction effects that resulted from supplementation of low-protein diets with leucine (Leu), valine (Val), and glycine-glutamic acid (Gly-Glu) on growing broiler chicks from 11 to 24 days old. Two levels of digestible Leu (1.07 and 1.50\%) and three levels of digestible $\mathrm{Val}(0.64,0.74$, and $0.84 \%)$ were investigated as a $2 \times 3$ factorial arrangement of treatments with 12 replicates. The diet with $1.07 \%$ digestible Leu and $0.84 \%$ digestible Val was supplemented with $0.34 \%$ Gly and $1.32 \%$ Glu as an additional treatment (T7). At 24 days old, $0.84 \%$ Val significantly improved feed conversion with $1.07 \%$ Leu, but $0.74 \%$ Val was sufficient with $1.50 \%$ Leu. The T7 diet further improved feed conversion. Increasing dietary $\mathrm{Val}$ from $0.64 \%$ to $0.74 \%$ significantly increased bone density and strength at the lower level of dietary Leu, while T7 significantly increased tibia breaking strength. There were significant Leu $\times$ Val interactions for villus height, crypt depth, and goblet cell numbers. Val at $0.84 \%$ maximized the development of the jejunum at the lower Leu level, while goblet cell number and crypt depth were impaired by increments of $\mathrm{Val}$ at the higher level of Leu. In conclusion, increasing the level of Val in low-protein grower diets significantly improved performance, bone and jejunum development of broilers, and its interaction with Leu was important. Therefore, these two amino acids (AAs) and the possibility of Gly-Glu fortification must be considered when formulating low-protein broiler diets.
\end{abstract}

Keywords: bone traits, branched-chain amino acids, broilers, gut histology, performance

\#Corresponding author: adabishahram@gmail.com

\section{Introduction}

Feed accounts for about $70 \%$ of the total cost of producing live broilers (Willems et al., 2013). A large portion of that cost involves meeting the crude protein (CP) and amino acid (AA) requirements of the broilers. By reducing the level of CP in the diet, it is possible to achieve significant cost savings (McGill, 2009). The introduction of commercial crystalline $\mathrm{Val}$ has potentially enabled the poultry industry to reduce further dietary CP and the cost of feed (Kidd et al., 1996). Valine has been proposed to be the fourth limiting AA after the sulphur AAs lysine and threonin, in vegetable diets based on corn and soybean meal (Corzo et al., 2009). Dietary strategies to reduce the CP content of broilers' diet by supplementing L-Val could lead to diets containing less soybean meal. However, elevated levels of feed grains such as corn may also lead to an imbalance of Leu and Val in broiler diets, because of the rich Leu content of corn compared with Val (Wu, 2013).

Leucine, isoleucine (lle) and Val are branched-chain amino acids (BCAAs), and antagonism among BCAAs in poultry has been described and documented. Increasing dietary Leu seems to increase Val and/or Ile requirements in chicks (D'Mello \& Lewis, 1970b; D'Mello, 1975). The antagonistic effect of Leu is more potent on Val than on Ile (D'Mello \& Lewis, 1970a). A reduction in feed intake (FI) and bodyweight gain (BWG) in broiler chickens because of the feeding an excess level of Leu has been reported (Burnham et al., 1992; Farran et al., 2003).

The altered AAs profile in low-CP broiler diets based on corn and soybean meal could lead to increased Leu level, which potentially limits the utilization of Val and the performance of the birds. Although 
various studies on the Val requirements of broilers have been documented (Corzo et al., 2004; Tavernari et al., 2013), there is limited research on the interaction of Leu and Val that are fed to fast-growing broilers in low-CP diets. A study by Ospina-Rojas et al. (2017) demonstrated the importance of Leu and Val interaction in low-CP finisher diets for broiler chickens from days 21 to 42 on performance, although this interaction was not significant for serum characteristics, carcass yield and diameter of muscle fibres.

The major problem of a low-CP broiler diet is impaired growth and meat yields. Dean et al. (2006) affirmed that even with supplementation of essential AAs, too much reduction of dietary protein may lead to a portion of the essential AAs being diverted to synthesis of nonessential AAs because of the lack of nonspecific nitrogen that would otherwise be used in this process. Berres et al. (2010) reported that inadequate nonessential AAs may also limit growth performance when diets are fed that are low in CP and L-Val. The requirement for Gly seems to be higher in diets that are low in CP than in diets with higher levels of CP (Dean et al., 2006). Glutamic acid has been included in the diet to provide a nitrogen source for the synthesis of nonessential AA.

The objective of the present study was to investigate effects of Leu and Val interaction and Gly-Glu fortifications in corn and soybean meal-based low-CP diets on growth performance, bone strength, and intestinal histomorphology of broilers chickens from day 10 to 24 post hatch.

\section{Materials and Methods}

All experimental protocols and animal care were approved by Ankara University Local Animal Care and Use Committee (number 2013-18-137). Eight hundred forty day-old Ross 308 male broilers were obtained from a commercial hatchery. All birds were raised in battery cages $(45 \times 43 \mathrm{~cm})$ that were equipped with two inside nipple drinkers and an outside galvanized feeder and received the same starter diets through the first ten days.

Table 1 Ingredients and calculated nutrient composition of starter and basal grower diets fed to broiler chicks $(\%$, as fed)

\begin{tabular}{lcc}
\hline Ingredients & Starter, fed days 0 to 10 & Basal grower for days 11 to 24 \\
\hline Corn & 41.31 & 42.27 \\
Soybean meal & 39.50 & 18.91 \\
Wheat, red & 10.00 & 29.08 \\
Sunflower oil & 4.66 & 3.96 \\
Dicalcium phosphate & 2.07 & 1.85 \\
Limestone & 1.21 & 1.18 \\
Sodium chloride & 0.30 & 0.10 \\
NaHCO3 & 0.04 & 0.59 \\
Vitamin premix & 0.10 & 0.10 \\
Mineral premix & 0.10 & 0.10 \\
Choline Cl -60 & 0.02 & 0.07 \\
DL-Methionine & 0.34 & 0.37 \\
L-Lysine HCl & 0.21 & 0.58 \\
L-Threonine & 0.10 & 0.26 \\
L- Arginine & & 0.29 \\
L-Valine & 0.04 & 0.04 \\
L- isoleucine & & 0.22 \\
L-Tryptophan & & 0.03
\end{tabular}

\footnotetext{
${ }^{1}$ Per kilogram of complete diet: vitamin A: 11,000 IU; vitamin $\mathrm{D}_{3}: 5000 \mathrm{IU}$; vitamin $\mathrm{E}: 80 \mathrm{mg}$; vitamin $\mathrm{K}_{3}: 3 \mathrm{mg}$; thiamine: 2 $\mathrm{mg}$; riboflavin; $6 \mathrm{mg}$; pyridoxine; $4 \mathrm{mg}$; pantothenic acid: $20 \mathrm{mg}$; niacin: $70 \mathrm{mg}$; folic acid: $1.750 \mathrm{mg}$; biotin: $200 \mathrm{mg}$; vitamin $B_{12}: 16 \mathrm{mg}$; antioxidant: $125 \mathrm{mg}$

${ }_{2}^{2}$ Provided per kilogram of complete diet: Cu: 16 mg; l: 2 mg, Se: 300 mg; Fe: 50 mg; Zn: 100 mg; Mn: 120 mg.
} 
Birds had ad libitum access to water and mash feed throughout the experiment. All cages were checked daily for general health and mortality. House temperature was gradually decreased from $33^{\circ} \mathrm{C}$ on the first day to $24{ }^{\circ} \mathrm{C}$ after three weeks old, then controlled thermostatically with a heater fan. Relative humidity was maintained at $50 \pm 5 \%$. Ventilation was accomplished by negative air pressure. The lighting programme throughout the experiment consisted of 23 hours of light and 1 hour of dark.

A corn, soybean meal and wheat-based diet was fed until the broilers were 10 days old (Table 1).

The basal grower diet (Table 1) to be fed from day 11 to day 24 was also based on corn, wheat, and soybean meal. It was formulated to meet all nutrient recommendations of Ross Breeders for Ross 308 broilers with regard to energy, Lys, phosphorus and calcium. All AAs (except Val and Leu) were adjusted to the Lys level using the ideal AA profile from Evonik (2010). The nutritional composition of both diets is shown in Table 2.

Table 2 Calculated nutrient composition of starter and basal grower diets fed to broiler chicks (\%, as fed)

\begin{tabular}{|c|c|c|}
\hline Calculated chemical content & Starter diet & Basal grower diet \\
\hline $\mathrm{ME}, \mathrm{Kcal} / \mathrm{kg}$ & 3030 & 3150 \\
\hline Crude protein & 22.76 & 16.50 \\
\hline Crude fibre & 2.37 & 2.25 \\
\hline Calcium & 1.03 & 0.92 \\
\hline Available phosphorus & 0.50 & 0.46 \\
\hline Potassium & 0.96 & 0.64 \\
\hline Chloride & 0.27 & 0.22 \\
\hline $\mathrm{Na}+\mathrm{K}-\mathrm{Cl}$, meq & 240.00 & 200.00 \\
\hline \multicolumn{3}{|c|}{ Standardized ileal digestible amino acids ${ }^{1}$} \\
\hline Methionine & 0.64 & 0.58 \\
\hline Cysteine & 0.30 & 0.23 \\
\hline Methionine + cysteine & 0.94 & 0.81 \\
\hline Lysine & 1.27 & 1.10 \\
\hline Threonine & 0.81 & 0.70 \\
\hline Valine & 0.95 & 0.64 \\
\hline Leucine & 1.59 & 1.07 \\
\hline Isoleucine & 0.85 & 0.75 \\
\hline Phenylalanine & 1.05 & 0.67 \\
\hline Tryptophan & 0.28 & 0.20 \\
\hline Histidine & 0.54 & 0.36 \\
\hline Glutamic acid & 3.77 & 2.15 \\
\hline Glycine & 0.70 & 0.48 \\
\hline
\end{tabular}

${ }^{1}$ standardized ileal digestible (SID) amino acid contents were calculated from the analysed amino acid levels in corn, soybean meal, and wheat, multiplying them by the corresponding SID coefficients (AminoDat, version 4.0, 2010).

Chicks were assigned to one of seven dietary treatments for evaluation from 11 to 24 days old (Table 3 ). There were 12 replications of 10 chicks of each treatment. The treatments consisted of two levels of standardized ileal digestible Leu (henceforth Leu) and three levels of SID Val (henceforth Val) $0.64 \%, 0.74 \%$, and $0.84 \%$ ) arranged as a $2 \times 3$ factorial. A seventh dietary treatment contained $1.07 \%$ Leu and $0.84 \%$ Val augmented with $0.34 \%$ L-Glycine and $1.32 \%$ glutamic acid. All raw materials (corn, wheat and soybean meal) were analysed for total AA, as prescribed by Liames and Fontaine (1994), and for dry matter and CP content, as prescribed by AOAC (2006) prior to the start of the experiment (Table 4). The experimental basal diet with reduced protein content was formulated by using the analysed total and calculated SID AA values of the ingredients (Table 4). Standardized ileal digestible AA values were estimated by multiplying the analysed AA levels by the SID coefficients as encoded in the AminoDat software (Version 4.0, 2010). The 
mixed rations were also analysed for total AA (Table 5) using methods described by Liames \& Fontaine (1994), and for dry matter and CP content using methods described in AOAC (2006).

Table 3 Supplemental regimes evaluated for feeding broiler chicks a basal diet that was low in protein

\begin{tabular}{llccc}
\hline \multirow{2}{*}{$\begin{array}{l}\text { Treatment } \\
\text { abbreviation }\end{array}$} & Starter phase (0 - 10 days) & \multicolumn{2}{c}{ Grower phase (11 - 24 days) } \\
\cline { 3 - 5 } T1 & Standard starter & 1.07 & 0.64 & L-Glycine + L-Glutamic acid, \% \\
\hline T2 & Standard starter & 1.07 & 0.74 & - \\
T3 & Standard starter & 1.07 & 0.84 & - \\
T4 & Standard starter & 1.50 & 0.64 & - \\
T5 & Standard starter & 1.50 & 0.74 & - \\
T6 & Standard starter & 1.50 & 0.84 & $0.34+1.32$ \\
T7 & Standard starter & 1.07 & 0.84 & - \\
\hline
\end{tabular}

Table 4 Analysed crude protein and amino acid contents of the major ingredients used in formulation of the starter and grower diets (\% in air dry feed)

\begin{tabular}{lccc}
\hline Protein and amino acids & Corn & Soybean meal & Wheat \\
\hline Crude protein & 7.30 & 46.14 & 10.13 \\
Methionine & $0.18(0.165)$ & $0.63(0.572)$ & $0.16(0.148)$ \\
Cysteine & $0.18(0.153)$ & $0.67(0.546)$ & $0.23(0.208)$ \\
Methionine + cysteine & $0.35(0.316)$ & $1.30(1.140)$ & $0.39(0.359)$ \\
Lysine & $0.24(0.220)$ & $2.78(2.499)$ & $0.32(0.272)$ \\
Threonine & $0.26(0.219)$ & $1.76(1.499)$ & $0.30(0.259)$ \\
Valine & $0.33(0.307)$ & $2.14(1.880)$ & $0.44(0.392)$ \\
Leucine & $0.79(0.744)$ & $3.47(3.088)$ & $0.67(0.602)$ \\
Arginine & $0.36(0.336)$ & $3.34(3.110)$ & $0.50(0.422)$ \\
Isoleucine & $0.24(0.227)$ & $2.06(1.833)$ & $0.34(0.322)$ \\
Histidine & $0.21(0.200)$ & $1.20(1.107)$ & $0.23(0.210)$ \\
Phenylalanine & $0.31(0.293)$ & $2.32(2.062)$ & $0.45(0.409)$ \\
Glutamic acid & $1.25(0.940)$ & $8.16(6.130)$ & $2.71(2.020)$ \\
Glycine & 0.30 & 1.97 & 0.43 \\
\hline
\end{tabular}

Values given in parentheses are the standardized ileal digestible values

Birds were weighed individually on arrival and on days 10 and 24. Feed consumption was measured for the periods of days 0 to 10 and 11 to 24 . Feed conversion was calculated for the same periods using $\mathrm{FI}$ and BWG for each replicate.

On day 24, three birds per pen that were nearest to the average pen weight were selected for further processing. Each bird was withdrawn from feed for six hours, weighed, leg-banded, exsanguinated by cutting the jugular vein, allowed to bleed for approximately $2 \mathrm{~min}$, and then eviscerated. The tibias were removed from individual birds and then sealed in plastic bags and stored at $-20{ }^{\circ} \mathrm{C}$ for further analysis. After thawing, the fat and meat on the bones were removed. Fat was extracted by placing the samples in the ethanol at 60 ${ }^{\circ} \mathrm{C}$ for four days by shaking and changing with fresh ethanol, followed by drying at $105^{\circ} \mathrm{C}$ for 16 hours. Right tibias (tibiotarsus) were used to determine bone density and breaking strength. A three-point bending test was used to test the force (Newtons $(\mathrm{N})$ ) that was needed to break the bone using a materials testing machine (Amatek, Lloyd Instruments) equipped with a load cell capacity of $500 \mathrm{~N}$, and operated with a 
crosshead speed of $5 \mathrm{~mm} /$ minute and $35.9 \mathrm{~mm}$ span. Bone density (specific gravity $\left(\mathrm{g} / \mathrm{cm}^{3}\right)$ ) was determined by Archimedes' method (Hempe et al., 1988) for first weighing tibias individually and then re-weighing in water in room temperature. Tibia density was then calculated as dry tibia weight / (dry tibia weight-wet tibia weight). The left tibias were used to determine ash, calcium, phosphorus, and magnesium content. The dry bones were incinerated at $550{ }^{\circ} \mathrm{C}$ for 12 hours in a muffle furnace to measure the ash content. The whole tibia ash was used to prepare mineral solution by dissolving ash in hydrochloric acid $(\mathrm{HCl})$ solution in its purest form (3: 1). After digestion, cooled solutions were transferred to acid cleaned volumetric flasks and diluted with de-ionized water. Calcium, phosphorus, and magnesium concentrations were determined according to EN 15510:2007 using Vista MPX type inductively coupled plasma-optical emission spectrometry

Table 5 Analysed total amino acids and protein composition of grower diets fed to broiler chicks (\% in air dry feeds)

\begin{tabular}{|c|c|c|c|c|c|c|c|}
\hline Crude protein and amino acids & $\mathrm{T} 1$ & $\mathrm{~T} 2$ & T3 & T4 & T5 & T6 & T7 \\
\hline Crude protein & 16.71 & 16.62 & 16.68 & 16.49 & 16.67 & 16.96 & 16.55 \\
\hline Alanine & 0.74 & 0.72 & 0.73 & 0.72 & 0.71 & 0.72 & 0.71 \\
\hline Arginine & 1.22 & 1.19 & 1.23 & 1.21 & 1.23 & 1.22 & 1.19 \\
\hline Aspartic acid & 1.42 & 1.37 & 1.42 & 1.40 & 1.38 & 1.39 & 1.37 \\
\hline Cysteine & 0.27 & 0.27 & 0.27 & 0.27 & 0.27 & 0.27 & 0.27 \\
\hline Glutamic acid & 2.96 & 2.92 & 2.97 & 2.98 & 2.91 & 2.94 & 4.03 \\
\hline Glycine & 0.66 & 0.64 & 0.66 & 0.65 & 0.64 & 0.65 & 0.99 \\
\hline Histidine & 0.39 & 0.38 & 0.39 & 0.39 & 0.38 & 0.38 & 0.38 \\
\hline Isoleucine & 0.83 & 0.81 & 0.84 & 0.80 & 0.82 & 0.81 & 0.80 \\
\hline Leucine & 1.24 & 1.21 & 1.23 & 1.61 & 1.63 & 1.64 & 1.20 \\
\hline Lysine & 1.18 & 1.16 & 1.22 & 1.14 & 1.23 & 1.20 & 1.16 \\
\hline Methionine + cysteine & 0.87 & 0.86 & 0.89 & 0.83 & 0.87 & 0.87 & 0.86 \\
\hline Methionine & 0.60 & 0.59 & 0.62 & 0.55 & 0.60 & 0.60 & 0.59 \\
\hline Phenylalanine & 0.74 & 0.72 & 0.74 & 0.74 & 0.72 & 0.73 & 0.72 \\
\hline Proline & 1.01 & 0.99 & 1.01 & 1.01 & 0.97 & 1.00 & 0.98 \\
\hline Serine & 0.72 & 0.73 & 0.74 & 0.73 & 0.72 & 0.73 & 0.72 \\
\hline Threonine & 0.78 & 0.78 & 0.80 & 0.76 & 0.79 & 0.78 & 0.77 \\
\hline Tryptophan & 0.21 & 0.20 & 0.21 & 0.20 & 0.20 & 0.21 & 0.21 \\
\hline Valine & 0.76 & 0.81 & 0.95 & 0.74 & 0.82 & 0.91 & 0.91 \\
\hline \multicolumn{8}{|l|}{ Synthetic amino acid levels } \\
\hline Arginine & 0.29 & 0.29 & 0.28 & 0.29 & 0.31 & 0.29 & 0.31 \\
\hline Glycine & $<0.01$ & $<0.01$ & $<0.01$ & $<0.01$ & $<0.01$ & $<0.01$ & 0.32 \\
\hline Isoleucine & 0.21 & 0.21 & 0.21 & 0.2 & 0.22 & 0.2 & 0.21 \\
\hline Leucine & $<0.01$ & $<0.01$ & $<0.01$ & 0.39 & 0.43 & 0.39 & $<0.01$ \\
\hline Lysine & 0.46 & 0.44 & 0.46 & 0.42 & 0.49 & 0.42 & 0.46 \\
\hline Methionine & 0.35 & 0.33 & 0.33 & 0.33 & 0.35 & 0.31 & 0.35 \\
\hline Treonin & 0.26 & 0.24 & 0.25 & 0.24 & 0.26 & 0.23 & 0.24 \\
\hline Valine & 0.04 & 0.13 & 0.23 & 0.04 & 0.14 & 0.22 & 0.23 \\
\hline
\end{tabular}


On day $24,3-3.5 \mathrm{~mL}$ of blood samples from six randomly selected males from each treatment were used to measure plasma cholesterol, uric acid, total protein, creatine, and total bilirubin levels. The blood was obtained from the jugular vein and immediately transferred to heparinised tubes. Blood samples were immediately put on ice in polystyrene foam and processed within two hours of collection. Plasma was separated by centrifuge ( $3500 \mathrm{rpm}$ for $15 \mathrm{~min}$ ) and stored at $-20^{\circ} \mathrm{C}$ for later analysis. The analysis of the plasma samples was performed by spectrophotometric methods using commercial kits (Pars Azmun, Tehran, Iran).

For the histological examinations, a 5-cm long segment of each jejunum was dissected at midpoint towards the proximal duodenum and flushed with saline solution $\left(18 \pm 1{ }^{\circ} \mathrm{C}\right)$. The segments that belonged to the same treatments were then fixed in $10 \%$ neutral buffered formalin at room temperature for 48 hours. After routine histological procedures, such as dehydration with increasing concentrations of ethanol, clearance with xylene, and embedding in paraffin wax, the samples were cut into sections at a thickness of 5 $\mu \mathrm{m}$ using a microtome and then placed on glass slides. The slides were then stained for neutral and acid mucins using alcian blue (AB) and periodic acid-Schiff (PAS) (Suvarna et al., 2012). Images were obtained with a computer-supported imaging system (Image J) connected to a light microscope (Leica DM 2500). The variables that were measured were villus height and width, villus length to crypt depth ratio, villus surface area, and total goblet cell numbers. Villus height was measured from the tip of the villus to the villus crypt junction, and the crypt depth was measured from its base up to the region of transition between the crypt and villus. Surface area was calculated using the following formula:

$$
(2 \pi) \times\left(\text { villus width/2) } \times\left(\text { villus length) } / 10^{6} \quad\right. \text { (Solis de los Santos et al., 2005). }\right.
$$

Data for all response variables that were related to the starter and grower phases were analysed as a completely randomized block design with six dietary treatments and 12 replicate blocks, using the general ANOVA procedure of SAS release 9.2 (SAS Institue, Inc., Cary, North Carolina, USA). Main effects and interactions between the main affects were calculated in a $2 \times 3$ factorial design, which included two levels of Leu and three levels of Val. Cage was the experimental unit for all analyses. All samples were analysed in triplicate and averaged. Means from T7 and T3 were compared by $t$ test. When significant differences $(P$ $<0.05)$ were found among groups, means were separated using the Tukey HSD test. Mortality results were assessed by chi-square test.

\section{Results}

From days 0 to 10, when all birds were fed the same starter diet, their growth, FI and FCR were similar across all treatments (data not shown).

Performance data for days 11 to 24 of the experiment are presented in Table 6 . The Leu $\times$ Val interaction was found significant for FCR $(P<0.05)$, but not for BW, BWG and FI $(P>0.05)$ in broilers fed low protein diets. While FCR was improved significantly only by $0.84 \%$ SID Val level at $1.07 \%$ SID dietary Leu, both $0.74 \%$ and $0.84 \%$ SID Val levels improved FCR significantly compared with $0.64 \%$ SID Val at $1.50 \%$ dietary SID Leu. Dietary SID Leu level had no effect on BW, BWG, $\mathrm{FI}$ and mortality $(P>0.05)$. But increasing the level of dietary SID Val from $0.64 \%$ to $0.74 \%$ and $0.84 \%$ resulted better BW, BWG and FCR $(P<0.05)$. Dietary inclusion of Gly and Glu had no effects on performance parameters except for FCR in the grower period. Glycine and glutamic acid supplementation improved FCR (Table 6) compared with T3 $(P<0.05)$.

Table 7 summarizes the data related to the chemical constituents of bone. While tibia ash (\% of dry matter) was influenced by the interaction between Leu and Val levels $(P<0.05)$, the $\mathrm{Ca}, \mathrm{P}$ and $\mathrm{Mg}$ content of tibia were not affected by the interaction $(P>0.05)$. Dietary Leu level as main factor had no significant effect on tibia parameters, except for the tibia relative weight. This parameter was higher in birds at $1.07 \%$ Leu compared with1.50\% Leu $(P<0.05)$. However, both higher levels of dietary Val resulted in improvement $(P$ $<0.05$ ) in tibia weight, ash and Ca content (\% of dry defatted bone) compared with $0.64 \%$ Val. Tibia weight was decreased $(P<0.05)$ by the addition of Gly-Glu. 
Table 6 Effects of dietary treatments on performance of broiler chicks during the growing period from 11 to 24 days of age during which time a low-protein basal diet was supplemented with L-Leucine, L-Valine, and glycine and glutamic acid

\begin{tabular}{|c|c|c|c|c|c|}
\hline Treatments $^{1}$ & BW, g & BWG, g & $\mathrm{FI}, \mathrm{g}$ & FCR, g:g & Mortality \\
\hline $\mathrm{T} 1$ & $967.9 \pm 11.5$ & $712.9 \pm 10.2$ & $1084.6 \pm 13.2$ & $1.52^{b} \pm 0.01$ & $2.50 \pm 1.31$ \\
\hline T2 & $984.9 \pm 12.7$ & $727.0 \pm 13.2$ & $1100.9 \pm 15.9$ & $1.52^{b} \pm 0.01$ & $1.67 \pm 1.12$ \\
\hline T3 & $986.5 \pm 11.3$ & $730.8 \pm 10.2$ & $1087.5 \pm 12.4$ & $1.49^{c} \pm 0.01$ & $0.83 \pm 0.83$ \\
\hline T4 & $954.5 \pm 10.2$ & $694.0 \pm 10.4$ & $1083.6 \pm 13.5$ & $1.56^{\mathrm{a}} \pm 0.01$ & $1.67 \pm 1.12$ \\
\hline T5 & $984.0 \pm 8.3$ & $727.0 \pm 6.4$ & $1106.5 \pm 11.4$ & $1.52^{b} \pm 0.01$ & $1.67 \pm 1.12$ \\
\hline T6 & $980.7 \pm 11.2$ & $724.5 \pm 9.7$ & $1100.0 \pm 16.7$ & $1.52^{b} \pm 0.01$ & $4.17 \pm 1.93$ \\
\hline $\mathrm{T} 7$ & $1018.6 \pm 10.0$ & $759.6 \pm 8.6$ & $1102.7 \pm 10.9$ & $1.45 \pm 0.01$ & $0.00 \pm 0.00$ \\
\hline \multicolumn{6}{|c|}{ Leucine main effect } \\
\hline $1.07 \%$ & $979.8 \pm 6.8$ & $723.5 \pm 6.5$ & $1091.0 \pm 7.9$ & $1.51 \pm 0.01$ & $1.67 \pm 0.63$ \\
\hline $1.50 \%$ & $973.0 \pm 6.0$ & $715.2 \pm 5.6$ & $1096.7 \pm 8.0$ & $1.53 \pm 0.01$ & $2.50 \pm 0.83$ \\
\hline \multicolumn{6}{|l|}{ Valine main effect } \\
\hline $0.64 \%$ & $961.2^{\mathrm{b}} \pm 7.6$ & $703.5^{\mathrm{b}} \pm 7.4$ & $1084.1 \pm 9.2$ & $1.54^{\mathrm{a}} \pm 0.01$ & $2.08 \pm 0.85$ \\
\hline $0.74 \%$ & $984.4^{a} \pm 7.4$ & $727.0^{a} \pm 7.2$ & $1103.7 \pm 9.6$ & $1.52^{b} \pm 0.01$ & $1.67 \pm 0.78$ \\
\hline $0.84 \%$ & $983.6^{a} \pm 7.8$ & $727.6^{a} \pm 6.9$ & $1093.8 \pm 10.3$ & $1.50^{b} \pm 0.01$ & $2.50 \pm 1.09$ \\
\hline \multicolumn{6}{|l|}{$P$-values } \\
\hline Leucine & 0.41 & 0.25 & 0.59 & 0.00 & 0.39 \\
\hline Valine & 0.04 & 0.01 & 0.33 & 0.00 & 0.78 \\
\hline Leucine $\times$ valine & 0.82 & 0.57 & 0.87 & 0.04 & 0.18 \\
\hline \multicolumn{6}{|l|}{ Contrast } \\
\hline T3 vs T7 & 0.127 & 0.096 & 0.474 & 0.008 & 0.339 \\
\hline
\end{tabular}

${ }^{1}$ T1: $1.07 \%$ standardized ileal digestible leucine (Leu) and 0.64\% valine (Val), T2: 1.07\% Leu and 0.74\% Val, T3: 1.07\% Leu and 0.84\% Val, T4: 1.50\% Leu and 0.64\% Val, T5: 1.50\% Leu and 0.74\% Val, T6: 1.50\% Leu and 0.84\% Val, T7: T3 with $0.34 \%$ glycine and $1.32 \%$ glutamic acid added

BW: bodyweight, BWG: body weight gain, FI: feed intake, FCR: feed conversion ratio

${ }^{a-d}$ Means within the same column without common superscripts are significantly different $(P<0.05)$

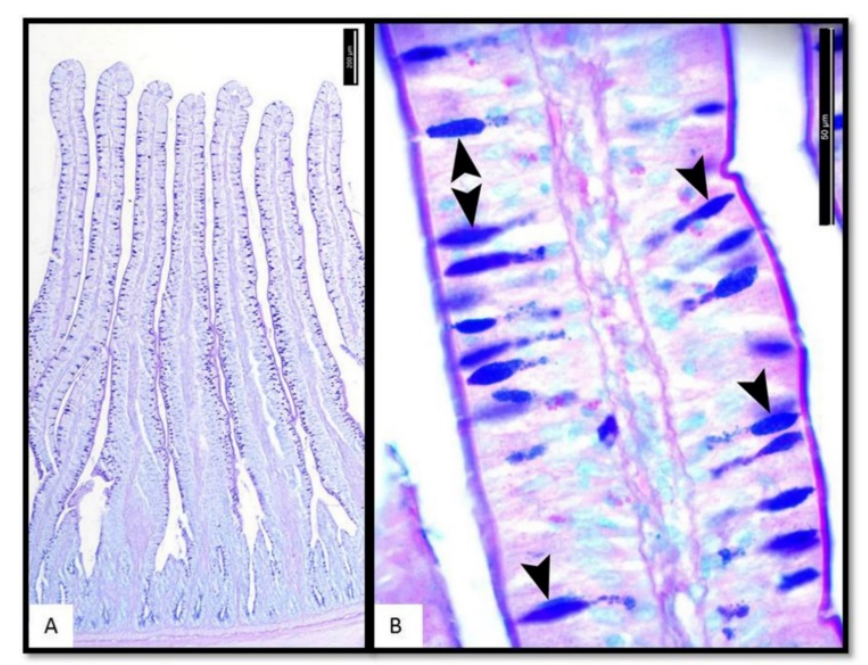

Figure 1 (A) General view of jejunal morphology at 21st day, bar $200 \mu \mathrm{m}$. (B) Arrowheads: goblet cells, bar $50 \mu \mathrm{m}$. Alcian blue (pH 2.5) and periodic acid-Schiff staining 
Table 7 Means ( \pm SE) of dietary treatments in which a low-protein basal diet was supplemented with LLeucine, L-Valine, and glycine and glutamic acid during grower period for bone mineral content (based on dry bone weight) of broiler chicks at 24 days old

\begin{tabular}{|c|c|c|c|c|c|c|}
\hline Treatments $^{1}$ & $\begin{array}{l}\text { Dry defatted } \\
\text { tibia weight }(\mathrm{g})\end{array}$ & $\begin{array}{c}\text { Tibia weight (\% } \\
\text { of live weight) }\end{array}$ & $\begin{array}{l}\text { Tibia ash } \\
\text { (\% of DM) }\end{array}$ & Tibia $\mathrm{Ca}^{2}$ & Tibia $\mathrm{P}^{2}$ & Tibia $\mathrm{Mg}^{2}$ \\
\hline $\mathrm{T} 1$ & $3.36 \pm 0.14$ & $0.90 \pm 0.01$ & $39.25^{b} \pm 0.13$ & $14.16 \pm 0.55$ & $6.44 \pm 0.22$ & $0.27 \pm 0.01$ \\
\hline T2 & $3.54 \pm 0.07$ & $0.91 \pm 0.01$ & $42.21^{a} \pm 0.53$ & $15.68 \pm 0.77$ & $7.24 \pm 0.36$ & $0.26 \pm 0.01$ \\
\hline Т3 & $3.52 \pm 0.08$ & $0.91 \pm 0.01$ & $40.46^{\mathrm{ab}} \pm 0.43$ & $15.10 \pm 0.67$ & $6.90 \pm 0.29$ & $0.25 \pm 0.01$ \\
\hline T4 & $3.30 \pm 0.05$ & $0.84 \pm 0.01$ & $40.24^{\mathrm{ab}} \pm 0.12$ & $14.28 \pm 0.55$ & $6.86 \pm 0.24$ & $0.26 \pm 0.004$ \\
\hline T5 & $3.57 \pm 0.07$ & $0.81 \pm 0.01$ & $39.27^{b} \pm 0.62$ & $14.80 \pm 0.26$ & $6.86 \pm 0.08$ & $0.26 \pm 0.004$ \\
\hline T6 & $3.64 \pm 0.10$ & $0.84 \pm 0.02$ & $41.62^{a} \pm 0.27$ & $15.24 \pm 0.50$ & $7.14 \pm 0.24$ & $0.27 \pm 0.01$ \\
\hline T7 & $3.49 \pm 0.13$ & $0.85 \pm 0.013$ & $41.58 \pm 0.28$ & $15.72 \pm 0.62$ & $7.30 \pm 0.20$ & $0.27 \pm 0.00$ \\
\hline \multicolumn{7}{|c|}{ Leucine main effect } \\
\hline $1.07 \%$ & $3.47 \pm 0.06$ & $0.90 \pm 0.01$ & $40.64 \pm 0.42$ & $14.98 \pm 0.39$ & $6.86 \pm 0.18$ & $0.26 \pm 0.01$ \\
\hline $1.50 \%$ & $3.50 \pm 0.06$ & $0.83 \pm 0.01$ & $40.37 \pm 0.35$ & $14.78 \pm 0.26$ & $6.95 \pm 0.11$ & $0.27 \pm 0.00$ \\
\hline \multicolumn{7}{|l|}{ Valine main effect } \\
\hline $0.64 \%$ & $3.33 \pm 0.07^{b}$ & $0.89 \pm 0.01$ & $39.74^{b} \pm 0.20$ & $14.22^{b} \pm 0.36$ & $6.65^{b} \pm 0.17$ & $0.27 \pm 0.00$ \\
\hline $0.74 \%$ & $3.55 \pm 0.05^{\mathrm{a}}$ & $0.88 \pm 0.01$ & $40.74^{\mathrm{ab}} \pm 0.67$ & $15.24^{\mathrm{a}} \pm 0.41$ & $7.053^{\mathrm{a}} \pm 0.18$ & $0.26 \pm 0.01$ \\
\hline $0.84 \%$ & $3.58 \pm 0.06^{a}$ & $0.88 \pm 0.01$ & $41.04^{\mathrm{a}} \pm 0.32$ & $15.17^{a} \pm 0.39$ & $7.02^{a} \pm 0.18$ & $0.26 \pm 0.01$ \\
\hline \multicolumn{7}{|l|}{$P$-values } \\
\hline Leucine & 0.65 & $<0.001$ & 0.46 & 0.55 & 0.53 & 0.56 \\
\hline Valine & 0.01 & 0.53 & 0.02 & 0.04 & 0.08 & 0.80 \\
\hline Leucine $\times$ Valine & 0.57 & 0.34 & $<0.001$ & 0.38 & 0.09 & 0.55 \\
\hline \multicolumn{7}{|l|}{ Contrast } \\
\hline T3 vs T7 & 0.784 & 0.008 & 0.089 & 0.583 & 0.360 & 0.240 \\
\hline
\end{tabular}

${ }^{1}$ T1: $1.07 \%$ standardized ileal digestible leucine (Leu) and 0.64\% valine (Val), T2: 1.07\% Leu and 0.74\% Val, T3: 1.07\% Leu and 0.84\% Val, T4: 1.50\% Leu and 0.64\% Val, T5: 1.50\% Leu and 0.74\% Val, T6: 1.50\% Leu and 0.84\% Val, T7: $1.07 \%$ Leu, $0.84 \%$ Val, $0.34 \%$ glycine, $1.32 \%$ glutamic acid

$2 \%$ of dry defatted bone

${ }^{\mathrm{a}-\mathrm{c}}$ Means within the same column without common superscripts are significantly different $(P<0.05)$

An interaction between the levels of dietary Leu and Val $(P<0.05)$ was observed for bone density and tibia breaking strength (Table 8 ). In the diet with $1.07 \%$ Leu content, both parameters were significantly increased with $0.74 \% \mathrm{Val}$ level, while just tibia breaking strength improved to $293.96 \mathrm{~N}$ from 223.8 only by $0.84 \%$ dietary Val level at $1.50 \%$ Leu level. Tibia density was decreased from 1.14 to $1.12 \mathrm{~g} / \mathrm{cm}^{3}$ by increasing dietary Leu level from $1.07 \%$ to $1.50 \%(P<0.05)$. In contrast, increasing dietary Val from 0.64 to $0.84 \%$ increased $(P<0.05)$ tibia density from 1.11 to $1.14 \mathrm{~g} / \mathrm{cm}^{3}$. Despite the significant decrease of tibia density by the supplementation of dietary Gly -Glu during the grower period, tibia breaking strength increased from 266.72 to 309.65 in T7 (Table 8) compared with T3 $(P<0.05)$.

The effects of the levels of Leu and Val, and Gly-Glu supplementation on plasma biochemistry are presented in Table 9. Dietary Leu and Val levels and their interaction were not significant for plasma cholesterol and creatine content. The interaction was significant for plasma uric acid, total protein and total bilirubin $(P<0.05)$. Plasma uric acid level decreased in low dietary Leu level $(1.07 \%)$ with increasing Val level to $0.84 \%$, while total protein and bilirubin increased $(P<0.05)$. However, at higher Leu level these parameters were not altered significantly by changes in dietary Val level. Plasma uric acid was increased and plasma total protein and bilirubine was decreased by the supplementation of Gly and Glu $(P<0.05)$. 
Table 8 Effects of L-Leucine and L-Valine during grower period on tibia density and breaking strength of broiler chicks at 24 days $^{1}$

\begin{tabular}{|c|c|c|c|c|c|}
\hline Treatments & $\begin{array}{c}\text { Tibia Ca } \\
\text { (\% of ash) }\end{array}$ & $\begin{array}{c}\text { Tibia } \mathrm{P} \\
\text { (\% of ash) }\end{array}$ & $\begin{array}{l}\text { Tibia Mg } \\
\text { (\% of ash) }\end{array}$ & $\begin{array}{c}\text { Tibia Density, } \\
\mathrm{g} / \mathrm{cm}^{3}\end{array}$ & $\begin{array}{c}\text { Tibia Breaking } \\
\text { Strength, Fmax-N }\end{array}$ \\
\hline T1 & $36.07 \pm 1.31$ & $16.41 \pm 0.53$ & $0.68 \pm 0.01$ & $1.11^{b} \pm 0.010$ & $263.5^{\mathrm{ab}} \pm 9.0$ \\
\hline $\mathrm{T} 2$ & $37.09 \pm 1.43$ & $17.13 \pm 0.65$ & $0.62 \pm 0.03$ & $1.15^{a} \pm 0.010$ & $303.4^{a} \pm 10.1$ \\
\hline T3 & $37.30 \pm 1.54$ & $17.05 \pm 0.68$ & $0.63 \pm 0.02$ & $1.15^{a} \pm 0.010$ & $266.7^{\mathrm{ab}} \pm 15.3$ \\
\hline $\mathrm{T} 4$ & $35.52 \pm 1.48$ & $17.05 \pm 0.66$ & $0.66 \pm 0.01$ & $1.12^{b} \pm 0.003$ & $223.9^{b} \pm 12.5$ \\
\hline T5 & $37.73 \pm 1.03$ & $17.48 \pm 0.39$ & $0.67 \pm 0.01$ & $1.10^{b} \pm 0.003$ & $271.3^{\mathrm{ab}} \pm 15.7$ \\
\hline T6 & $36.65 \pm 1.34$ & $17.18 \pm 0.63$ & $0.64 \pm 0.01$ & $1.13_{b} \pm 0.004$ & $294.0^{\mathrm{a}} \pm 19.4$ \\
\hline $\mathrm{T7}$ & $37.55 \pm 1.51$ & $17.44 \pm 0.50$ & $0.65 \pm 0.01$ & $1.12 \pm 0.005$ & $309.7 \pm 9.1$ \\
\hline \multicolumn{6}{|c|}{ Leucine main effect } \\
\hline $1.07 \%$ & $36.82 \pm 0.76$ & $16.86 \pm 0.34$ & $0.64 \pm 0.01$ & $1.14 \pm 0.01$ & $277.9 \pm 7.2$ \\
\hline $1.50 \%$ & $36.63 \pm 0.73$ & $17.24 \pm 0.30$ & $0.66 \pm 0.01$ & $1.12 \pm 0.01$ & $262.8 \pm 10.2$ \\
\hline \multicolumn{6}{|l|}{ Valine main effect } \\
\hline $0.64 \%$ & $35.79 \pm 0.92$ & $16.73 \pm 0.41$ & $0.67 \pm 0.01$ & $1.11^{b} \pm 0.01$ & $243.68^{b} \pm 8.51$ \\
\hline $0.74 \%$ & $37.41 \pm 0.82$ & $17.31 \pm 0.35$ & $0.65 \pm 0.01$ & $1.13^{\mathrm{a}} \pm 0.01$ & $287.25^{a} \pm 9.71$ \\
\hline $0.84 \%$ & $36.98 \pm 0.95$ & $17.11 \pm 0.43$ & $0.64 \pm 0.01$ & $1.14^{\mathrm{a}} \pm 0.01$ & $280.09^{a} \pm 12.4$ \\
\hline \multicolumn{6}{|l|}{$P$-values } \\
\hline Leucine & 0.79 & 0.19 & 0.41 & $<0.001$ & 0.19 \\
\hline Valine & 0.16 & 0.23 & 0.24 & $<0.001$ & $<0.01$ \\
\hline Leucine $\times$ Valine & 0.69 & 0.74 & 0.14 & $<0.001$ & 0.04 \\
\hline \multicolumn{6}{|l|}{ Contrast } \\
\hline T-3 vs T-7 & 0.74 & 0.94 & 0.62 & 0.001 & 0.02 \\
\hline
\end{tabular}

${ }^{1}$ T1: $1.07 \%$ standardized ileal digestible leucine (Leu) and 0.64\% valine (Val), T2: 1.07\% Leu and 0.74\% Val, T3: 1.07\% Leu and 0.84\% Val, T4: 1.50\% Leu and 0.64\% Val, T5: 1.50\% Leu and 0.74\% Val, T6: 1.50\% Leu and 0.84\% Val, T7: $1.07 \%$ Leu, $0.84 \%$ Val, $0.34 \%$ glycine, $1.32 \%$ glutamic acid

${ }^{\mathrm{a}-\mathrm{c}}$ Means within the same column without common superscripts are significantly different $(P<0.05)$

The jejunal histomorphology and data are presented in Figure 1 and Table 10. The interaction between Leu and Val level was significant for villus height, crypt depth, villus length to crypt depth ratio and total goblet cell number. The villus height increased $(P<0.05)$ from $1168.2 \mu \mathrm{m}$ to $1294.5 \mu \mathrm{m}$ with increasing Val level from $0.64 \%$ to $0.84 \%$ at low Leu level (1.07\%), while at a high level of Leu $(1.50 \%)$ villus height improved significantly at $0.74 \% \mathrm{Val}$, but no additional improvement was obtained with $0.84 \%$ Val. 
Table 9 Effects of different levels of L-Leucine and L-Valine during grower period on some blood plasma biochemistry parameters of broiler chicks at 24 days $^{1}$

\begin{tabular}{|c|c|c|c|c|c|}
\hline Treatments & $\begin{array}{c}\text { Cholesterol } \\
(\mathrm{mg} / \mathrm{dL})\end{array}$ & $\begin{array}{c}\text { Uric acid } \\
(\mathrm{mg} / \mathrm{dL})\end{array}$ & $\begin{array}{c}\begin{array}{c}\text { Total protein } \\
(\mathrm{g} / \mathrm{dL})\end{array} \\
\end{array}$ & $\begin{array}{c}\text { Creatinine } \\
(\mathrm{mg} / \mathrm{dL})\end{array}$ & $\begin{array}{c}\text { Total bilirubine } \\
(\mathrm{mg} / \mathrm{dL})\end{array}$ \\
\hline $\mathrm{T} 1$ & $126.6 \pm 2.12$ & $6.48^{a} \pm 0.14$ & $3.47^{b} \pm 0.06$ & $0.51 \pm 0.02$ & $0.43^{b} \pm 0.02$ \\
\hline $\mathrm{T} 2$ & $125.3 \pm 1.82$ & $6.35^{a} \pm 0.20$ & $3.33^{b} \pm 0.06$ & $0.48 \pm 0.02$ & $0.47^{\mathrm{ab}} \pm 0.01$ \\
\hline T3 & $130.0 \pm 4.14$ & $4.45^{b} \pm 0.16$ & $4.05^{\mathrm{a}} \pm 0.04$ & $0.51 \pm 0.03$ & $0.51^{a} \pm 0.02$ \\
\hline T4 & $126.1 \pm 1.91$ & $5.10^{b} \pm 0.18$ & $3.36^{b} \pm 0.09$ & $0.53 \pm 0.03$ & $0.43^{b} \pm 0.01$ \\
\hline T5 & $128.0 \pm 2.07$ & $4.67^{b} \pm 0.10$ & $3.42^{b} \pm 0.14$ & $0.46 \pm 0.03$ & $0.47^{\mathrm{ab}} \pm 0.01$ \\
\hline T6 & $125.0 \pm 1.45$ & $4.90^{b} \pm 0.19$ & $3.47^{b} \pm 0.05$ & $0.51 \pm 0.03$ & $0.41^{b} \pm 0.02$ \\
\hline $\mathrm{T} 7$ & $130.26 \pm 4.42$ & $5.78 \pm 0.14$ & $3.77 \pm 0.04$ & $0.51 \pm 0.02$ & $0.44 \pm 0.02$ \\
\hline \multicolumn{6}{|l|}{ Leu main effect } \\
\hline $1.07 \%$ & $127.3 \pm 1.64$ & $5.76 \pm 0.24$ & $3.62 \pm 0.08$ & $0.50 \pm 0.01$ & $0.47 \pm 0.01$ \\
\hline $1.50 \%$ & $126.4 \pm 1.04$ & $4.89 \pm 0.10$ & $3.41 \pm 0.05$ & $0.50 \pm 0.02$ & $0.43 \pm 0.01$ \\
\hline \multicolumn{6}{|l|}{ Valine main effect } \\
\hline $0.64 \%$ & $126.3 \pm 1.36$ & $5.79^{a} \pm 0.23$ & $3.42^{b} \pm 0.05$ & $0.52 \pm 0.02$ & $0.43 \pm 0.01$ \\
\hline $0.74 \%$ & $126.7 \pm 1.38$ & $5.51^{a} \pm 0.28$ & $3.37^{b} \pm 0.07$ & $0.47 \pm 0.01$ & $0.48 \pm 0.01$ \\
\hline $0.84 \%$ & $127.5 \pm 2.23$ & $4.67^{b} \pm 0.14$ & $3.76^{\mathrm{a}} \pm 0.09$ & $0.51 \pm 0.01$ & $0.46 \pm 0.02$ \\
\hline \multicolumn{6}{|l|}{$P$-values } \\
\hline Leu & 0.66 & $<0.001$ & $<0.001$ & 1.00 & 0.02 \\
\hline Val & 0.89 & $<0.001$ & $<0.001$ & 0.12 & 0.09 \\
\hline Leucine $\times$ Valine & 0.32 & $<0.001$ & $<0.001$ & 0.78 & 0.01 \\
\hline \multicolumn{6}{|l|}{ Contrast } \\
\hline T3 vs T7 & 0.95 & 0.0001 & 0.005 & 0.77 & 0.01 \\
\hline
\end{tabular}

${ }^{1}$ T1: $1.07 \%$ standardized ileal digestible leucine (Leu) and 0.64\% valine (Val), T2: 1.07\% Leu and 0.74\% Val, T3: 1.07\% Leu and 0.84\% Val, T4: 1.50\% Leu and 0.64\% Val, T5: 1.50\% Leu and 0.74\% Val, T6: 1.50\% Leu and 0.84\% Val, T7: $1.07 \%$ Leu, $0.84 \%$ Val, $0.34 \%$ glycine and $1.32 \%$ glutamic acid

${ }^{a-b}$ Means within the same column without common superscripts are significantly different $(P<0.05)$.

Crypt depth in birds fed lower level of (1.07\%) Leu was decreased by $14.77 \%$ for dietary $0.84 \%$ Val level compared with $0.64 \%$ (182.8 and $155.8 \mu \mathrm{m}$, respectively) $(P<0.05)$. On the other hand, at $1.50 \%$ Leu level, crypt depth increased by $33.41 \%$ and $25.36 \%(P<0.05)$ for dietary $0.74 \%$ and $0.84 \%$ Val, respectively. Villus length to crypt depth ratio increased with increasing Val levels in birds fed low Leu (1.07\%), so that birds that received the diet with $0.84 \% \mathrm{Val}$ had the highest ratio in comparison with the other Val levels. Total goblet cell number in $1.07 \%$ Leu was increased by raising the Val level from $0.64 \%$ to $0.84 \%$, while it was not influenced significantly at high dietary Leu level. Regarding the effect of dietary Gly-Glu supplementation in low-CP broiler diets, villus height, villus length to crypt depth ratio and total goblet cell number were higher in T3, whereas crypt depth and villus width was higher in birds that received the Gly-Glu supplemented feed $(P<0.05)$ (Figure 2). 
Table 10 Effects of different levels of L-Leucine and L-Valine during grower period on jejunum villus parameters of broiler chicks at 24 days ${ }^{1}$

\begin{tabular}{|c|c|c|c|c|c|c|}
\hline Treatments & $\begin{array}{c}\text { Villus height, } \\
\mu \mathrm{m}\end{array}$ & $\begin{array}{c}\text { Crypt depth, } \\
\mu \mathrm{m}\end{array}$ & $\begin{array}{c}\text { Villus wide, } \\
\mu \mathrm{m}\end{array}$ & $\begin{array}{l}\text { Villus length to } \\
\text { Crypt depth }\end{array}$ & $\begin{array}{l}\text { Villus surface } \\
\text { area, } \mathrm{mm}^{2}\end{array}$ & $\begin{array}{c}\text { Total goblet cell } \\
\text { number }\end{array}$ \\
\hline $\mathrm{T} 1$ & $1168.2^{c} \pm 26.9$ & $182.8^{\mathrm{b}} \pm 5.8$ & $176.1 \pm 5.3$ & $6.77^{\mathrm{b}} \pm 0.41$ & $0.64 \pm 0.03$ & $147.9^{d} \pm 10.4$ \\
\hline $\mathrm{T} 2$ & $1184.7^{c} \pm 28.3$ & $171.7^{\mathrm{b}} \pm 3.6$ & $196.1 \pm 8.8$ & $7.15^{b} \pm 0.20$ & $0.73 \pm 0.04$ & $210.7^{b} \pm 12.5$ \\
\hline T3 & $1294.5^{b} \pm 22.6$ & $155.8^{c} \pm 3.1$ & $177.7 \pm 5.6$ & $8.52^{a} \pm 0.27$ & $0.73 \pm 0.03$ & $249.2^{\mathrm{a}} \pm 11.7$ \\
\hline T4 & $1310.9^{b} \pm 25.8$ & $157.7^{c} \pm 3.7$ & $162.9 \pm 7.5$ & $8.60^{a} \pm 0.16$ & $0.68 \pm 0.04$ & $186.2^{\mathrm{bc}} \pm 12.5$ \\
\hline T5 & $1426.6^{a} \pm 13.7$ & $210.4^{a} \pm 7.7$ & $161.0 \pm 9.0$ & $7.05^{b} \pm 0.28$ & $0.72 \pm 0.05$ & $153.8^{\mathrm{cd}} \pm 20.2$ \\
\hline T6 & $1359.9^{\mathrm{ab}} \pm 12.6$ & $197.7^{\mathrm{a}} \pm 2.0$ & $162.1 \pm 2.9$ & $7.01^{b} \pm 0.06$ & $0.69 \pm 0.01$ & $153.7^{\mathrm{cd}} \pm 7.0$ \\
\hline $\mathrm{T} 7$ & $1113.8 \pm 33.8$ & $175.1 \pm 12.3$ & $205.4 \pm 10.6$ & $7.16 \pm 0.39$ & $0.73 \pm 0.03$ & $172.6 \pm 8.2$ \\
\hline \multicolumn{7}{|c|}{ Leucine main effect } \\
\hline $1.07 \%$ & $1215.8 \pm 24.2$ & $170.09 \pm 3.2$ & $183.3 \pm 4.3$ & $7.48 \pm 0.22$ & $0.701 \pm 0.02$ & $202.6 \pm 10.4$ \\
\hline $1.50 \%$ & $1365.8 \pm 13.8$ & $188.61 \pm 5.2$ & $162.0 \pm 4.4$ & $7.55 \pm 0.18$ & $0.695 \pm 0.02$ & $164.6 \pm 8.5$ \\
\hline \multicolumn{7}{|l|}{ Valine main effect } \\
\hline $0.64 \%$ & $1239.5^{\mathrm{a}} \pm 34.89$ & $170.3^{b} \pm 4.53$ & $169.5 \pm 4.73$ & $7.69 \pm 0.31$ & $0.66 \pm 0.02$ & $167.1^{b} \pm 9.2$ \\
\hline $0.74 \%$ & $1305.7^{\mathrm{ab}} \pm 33.1$ & $191.0^{\mathrm{a}} \pm 6.24$ & $178.6 \pm 8.04$ & $7.10 \pm 0.17$ & $0.73 \pm 0.03$ & $182.2^{\mathrm{ab}} \pm 13.2$ \\
\hline $0.84 \%$ & $1327.2^{b} \pm 14.9$ & $176.8^{b} \pm 5.38$ & $169.9 \pm 3.59$ & $7.76 \pm 0.23$ & $0.71 \pm 0.02$ & $201.4^{\mathrm{a}} \pm 13.3$ \\
\hline \multicolumn{7}{|l|}{$P$-values } \\
\hline Leu & 0.0001 & 0.0001 & 0.001 & 0.75 & 0.85 & 0.0007 \\
\hline Val & 0.022 & 0.0003 & 0.41 & 0.15 & 0.19 & 0.03 \\
\hline Leucine $\times$ Valine & 0.03 & 0.0001 & 0.30 & 0.0001 & 0.67 & 0.0001 \\
\hline \multicolumn{7}{|l|}{ Contrast } \\
\hline T3 vs T7 & 0.001 & 0.043 & 0.012 & 0.004 & 0.989 & 0.001 \\
\hline
\end{tabular}

${ }^{1}$ T1: 1.07\% standardized ileal digestible leucine (Leu) and 0.64\% valine (Val), T2: 1.07\% Leu and 0.74\% Val, T3: 1.07\% Leu and 0.84\% Val, T4: 1.50\% Leu and 0.64\% Val, T5: 1.50\% Leu and 0.74\% Val, T6: 1.50\% Leu and 0.84\% Val, T7: $1.07 \%$ Leu, $0.84 \%$ Val, $0.34 \%$ glycine and $1.32 \%$ glutamic acid

${ }^{a-d}$ Means within the same column without common superscripts are significantly different $(P<0.05)$

\section{Discussion}

It is generally expected that an increase in one essential AA would lead to an increased need for the next limiting essential AA to avoid protein synthesis limitations and decreased growth. In the current study, with low-protein broiler diets, increasing Leu level from 1.07\% to $1.50 \%$ caused an impaired FCR (Table 6). However, FCR and BWG were influenced positively by increasing dietary Val from $0.64 \%$ to $0.74 \%$ and $0.84 \%$. The interaction between the levels of Leu and Val on FCR (Table 6), which was improved by increasing dietary Val to $0.84 \%$ at $1.07 \%$ Leu, in contrast to $0.74 \%$ at $1.50 \%$ Leu. The adverse effect of Leu was relatively more potent at high Leu level (1.50\%) (Table 6). It was reported that the addition of excess Leu to a diet that was limited in Val precipitated a severe growth depression in young chicks and that this adverse effect could be reversed with Val supplementation (D'Mello \& Lewis, 1970b). Antagonistic effects of a Leu imbalance, decreasing FI and BWG, were reported (Ospina-Rojas et al., 2017), impairing the immune system, and increasing leg problems (Farran \& Thomas, 1992a; 1992b).

In a recent study, Ospina-Rojas et al. (2017) reported that dietary Leu levels above $1.19 \%$ in lowprotein diets had an antagonistic effect on Val, impairing broiler performance, which supports the results of the current experiment. This would explain the poor broiler performance during the grower phase with higher 


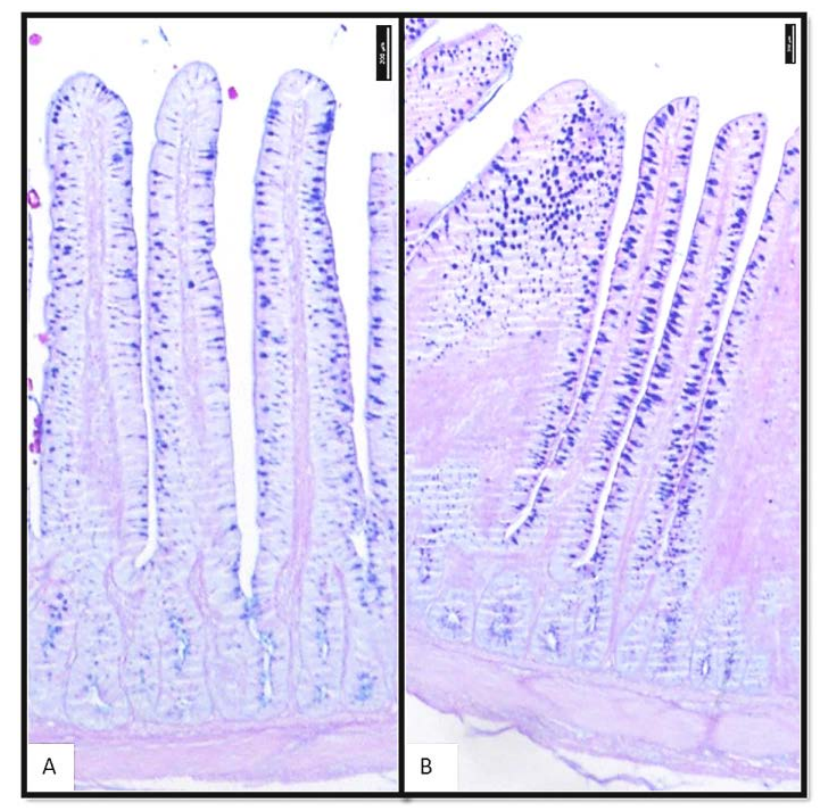

Figure 2 Comparison of numbers of goblet cells between T1 (1.07\% Leu and 0.64 Val) (A) and T3 (1.07\% Leu and $0.84 \mathrm{Val})(\mathrm{B})$, bar $200 \mu \mathrm{m}$

dietary Leu level at $1.50 \%$ in this study. Harper et al. (1984) revealed that in low-protein diets, Leu may accelerate the degradation of other BCCAs, mainly in muscles, through the stimulated activity of branched chain alpha-ketoacid dehydrogenase (BCKD), which lowers Val and Ile in tissues. Ospina-Rojas et al. (2017) stated that a high Leu level can stimulate the catabolism of Val by increasing the intracellular concentration of $\alpha$-ketoisocaproate (KIC), and by promoting indirectly the activation of BCKD complex. Brosnan \& Brosnan (2006) revealed that Leu supplementation increases the formation of KIC, an $\alpha$-keto acid of Leu that is formed from the first reaction of the catabolism of this AA. The current findings on BWG and FCR improvement in the present study during the grower phase with an increased Val level may be attributed to increasing $V a$ al requirement owing to more catabolism arising from Leu antagonism. Feed conversion ratio from 11 to 24 days old was significantly improved by inclusion of Gly + Glu in T7 compared with T3 (Table 6). The inadequate amount of Glu and Gly is the best-known reason for the reduction in performance of broilers that are given low-protein diets. One explanation for impaired performance with low protein is a deficiency innon-specific nitrogen for the synthesis of nonessential AAs (Aftab et al., 2006). Corzo et al. (2004) reported that the Gly + Serine (Ser) requirement of broiler is $1.80 \%$ in a low-protein broiler diet. However, Dean et al. (2006) recommended no less than $2.32 \%$ Gly + Ser in low-CP corn-soybean meal broiler diet from 0 to 17 days. In the current study, Glu and Gly + Ser content of the basal diet were $2.97 \%$ and $1.40 \%$, respectively, which are lower than recommended, but reached $4.03 \%$ and $1.71 \%$, respectively (Table 4 ) in the Glu-Gly supplemented group (T7). The best FCR that was obtained by Gly-Glu supplementation in the current research could be attributed to meeting the requirement of nonessential AAs for optimal broiler growth when low-CP broiler diets introduced. These results are in line with those of Berres et al. (2010), who revealed that broilers fed diets supplemented with Val + Glu, Val + Ile + Gly, and Val + Ile + Gly + Glu had better $(P \leq 0.05)$ FCR than birds that received diets that contained Val + Ile. Dean et al. (2006) also concluded that growth performance and FCR of broilers received the additional Gly in an AA-supplemented $16 \%$ CP diet was similar to broilers fed on diet containing 22\% CP. Corzo et al. (2005) also found positive effects from supplementing reduced-CP diets with nonessential AA.

Weak bones result in breakages during processing and lower meat grade. Also, weak legs often result in reduced $\mathrm{FI}$, thus affecting BWG (Onyango et al., 2003). In the current study, increasing dietary Val (independent of Leu) had significant effects on the integrity of the tibia. This is interesting in that more Val was needed at higher dietary Leu level to improve the bone strength than at lower Leu level, indicating that the antagonistic effects of Leu on Val are more potent at 1.50\% Leu in low-CP broiler diets (Table 8).

Farran and Thomas (1992b) studied the relationship between leg problems and Val deficiency in broiler chicks and found that bone ash and calcium content were lowest for Val-deficient birds. Abnormalities of legs and feathers have also been reported when broilers were fed a Val-deficient diet (Farran \& Thomas, 1992a; 1992b), but this appeared in studies in which deficiencies were more severe. More recently, Foroudi 
\& Rezamand (2014) fed broilers with three levels of Val $(0.74 \%, 0.80 \%$ and $0.86 \%)$ for 15 days and reported that birds fed on diet containing $0.86 \%$ Val had higher $(P<0.05)$ level of Ca concentration $\mathrm{mg} / \mathrm{g}$ of dried bone compared with $0.74 \%$ and $0.80 \%$ Val. The relationship between increased dietary Val up to $0.84 \%$ and improved bone integrity could be attributed to the function of $\mathrm{Val}$ in collagen formation, and calcium excretion in the urine. Collagen is a fibrous protein that ensures bone strength and flexibility and consists of $90-95 \%$ of organic compounds, which represent $30 \%$ of bone tissue (Straková et al., 2009). According to Farran and Thomas (1992b), plasma hydroxyproline was lowest in birds fed a Val-deficient diet $(P<0.05)$, indicating that a reduction in bone collagen breakdown and fractional excretion of calcium in Val-deficient birds (13\%) was three times higher than those of Val-supplemented birds. Therefore, it can be speculated that Val and its interaction with Leu play important roles in bone development. According to the authors' knowledge, this study demonstrates for the first time the significant relationship between bone strength and dietary Val and Leu in broiler chickens fed low-CP diets.

Total plasma protein levels may increase by raising the intake of protein via diet (Leveille \& Sauberlich, 1961). Decreased plasma total protein level may result from gluconeogenesis and deficiency or imbalances inAAs. A lack of CP supply, mostly from nonessential AAs, may lead to a shortage of these substrates in the blood plasma of chickens (Corzo et al., 2011). As a result, plasma total protein level may provide a potential source to determine dietary protein and/or AA deficiencies and imbalances (Leresche et al., 1974; Wills, 1985). Plasma total protein ranges from 3.0 to 5.5 (g/dL) (Ritchie et al., 1994). In the current study, plasma total protein ranged from 3.33 to $4.05(\mathrm{~g} / \mathrm{dL})$. In contrast to the current findings, no reduction or increase in total plasma protein was reported by Corzo et al. (2005) when feeding birds with low-protein diet supplemented with essential and nonessential AAs. The final product of protein catabolism in chickens is uric acid, which is used as a criterion for determining protein bioavailability. Dietary protein sources with higher biological values cause lower uric acid concentration in the blood serum compared with those of lower biological values (Hevia \& Clifford, 1977). On the other hand, high serum uric acid in the blood shows excess AA intake, while poor AA absorption is associated with lower serum uric acid (Namroud et al. 2008). Uric acid ranges between 2.5 and $8.1(\mathrm{mg} / \mathrm{dL})$ and there is a direct relation between the amount of ingested protein and plasma uric acid level (Szabo et al., 2005). In the present study there was a significant interaction affecting plasma uric acid $(P<0.05)$. For birds fed the diet that contained $1.07 \%$ Leu plasma uric acid decreased when $0.84 \%$ Val was provided. However, for birds fed the diet that contained $1.50 \%$ Leu plasma uric acid levels remained constant across all levels of Val supplementation. Namroud et al. (2008) observed a reduction in uric acid levels as the result of low dietary protein level. According to Sklan and Plavnik (2002), a high level of deamination process in feeding birds with a diet containing excessive or imbalanced AA causes more energy expenditure and nitrogen excretion as uric acid. Therefore, Val supplementation may decrease the serum concentrations of uric acid because of increased utilization of BCAAs in the AA pool by reducing excretion of nitrogen compounds, thereby contributing to improved broiler performance in the current experiment.

Creatinine, as a by-product of phosphocreatine breakdown (nonenzymatic conversion) in skeletal muscle, is another important indicator of protein metabolism because its concentration is directly related to muscle mass, age, physical activity, and diet (Szabo et al., 2005). The normal range of creatine in healthy birds is between 0.31 and $1.8(\mathrm{mg} / \mathrm{dL}$ ) (Ritchie et al., 1994). Parallel with the current findings, Gheorghe et al. (2013) observed that the plasma levels of creatinine were not affected by dietary protein level. A high level of bilirubin, which is the main breakdown product of haemoglobin, and a member of the antioxidant family, indicates inefficient lymphatic or liver-gall bladder function. Despite not being useful for clinical information because of the very low quantity in avian plasma, studies in human and animals have shown that bilirubin acts as an essential physiological cytoprotectant, which might diminish oxidative stress in the blood (Sedlak \& Snyder, 2004; Scholtz et al., 2009).

The major site of AA and peptide absorption along the intestinal tract is located at jejunum level, but other parts of the small intestine have significant transport capacity (Silk et al., 1985; Richards et al., 2005) Feed conversion ratio was improved in birds that were fed a diet containing $1.07 \%$ Lue and $0.84 \%$ Val (T3 and T7) relative to all other diets and supplementation with glycine and glutamic acid provided further improvement (T3 vs. T7). The birds that were provided 1.07\% Lue had improved jejunum development, as indicated by their increased villus length to crypt depth ratio and total goblet cell number as a function of the level of Val supplementation $(P<0.05)$. However, this effect of Val supplementation was either reversed or not significant in birds fed $1.50 \%$ Lue. It seems that improvement in all intestinal morphometric parameters in the birds fed T3 resulted in a decreased turnover of the intestinal mucosa. A lower turnover in intestinal epithelium leads to lower maintenance requirement, which eventually results in higher growth and better FCR in birds (Van Nevel et al., 2005). So, any changes in intestinal morphometric structure may affect nutrient metabolizability and performance. For example, shorter villi and deeper crypt may cause poor nutrient absorption and lower performance (Xu et al., 2003). However, little is known about the impact of Val 
and Leu, and their interaction on the intestinal development in broiler chicks. Ren et al. (2015) found that BCAA supplementation significantly increased villus height in the duodenum and decreased crypt depth in the jejunum compared with pigs that were fed low-protein diets $(17.06 \% \mathrm{CP})$. In the current study the protein content was between $16.57 \%$ and $17.08 \%$ in the grower diets. This low protein can limit the nonessential AA supply, such as Glu, Gly, Ser, and alanine (Ala), which are known to be important for gut development. If a diet does not provide nonessential AAs or an additional source of nitrogen, the nonessential AAs would be synthesized from other essentials that include AA. Amino acids, rather than glucose, are mentioned as the major fuel for the small intestinal mucosa (Wu, 1998). Use of Gly by the small intestinal mucosa to synthesize glutathione (GSH) is a physiologically important pathway (Reeds et al., 1997), but the role of Gly as a powerful cytoprotectant has only recently been recognized. So, it can be assumed that the level of nonessential AAs that was provided in the present experiment could cause deficiency in energy supply to meet the requirement of intestinal mucosa with supplemental Val serving as a precursor of Glu, Gly and glutamin (GIn). One mode of action of dietary BCAA in improving the intestinal morphometric parameters is accelerating the absorption of synthetic AA (Stoll et al., 1998). Branched chain amino acids also provide an amino group and nitrogen for the synthesis of nonessential AAs such as aspartate (Asp), Glu, and Ala in the small intestine $(\mathrm{Wu}, 2013)$. In piglets that received protein in milk, $40 \%$ of $\mathrm{Val}, 30 \%$ of lle and $40 \%$ of Leu in the diet were extracted by portal-drained viscera (PDV) tissues with $<20 \%$ of the extracted BCAA utilized for intestinal mucosal protein synthesis (Stoll et al., 1998). Although some studies focused on the utilization of Leu by intestinal mucosa, there is very limited information on Val. Some studies of young pigs show that about $15 \%$ to $30 \%$ of the whole-body phenylalanine and Leu stream is metabolized by the PDV tissues (Bush et al., 2001; Van der Schoor et al., 2001). Based on the importance of nonessential AAs in gut development, special care should be taken to meet those functional AA requirements when low-protein diets are used. The improvement in the jejunum that was observed here with increasing Val level may be attributed to the utilization of dietary Val as a precursor of nonessential AAs in the mucosa. In spite of the importance of nonessential AAs and probable contribution of $\mathrm{Val}$ in the gut development, dietary augmentation with Gly and Glu had little effect on jejunum development even though T7 had the best FCR. The observed interaction of Lue and Val affecting the intestinal mucosa indicate further research will be needed to clearify the underlying mechanism for this effect.

\section{Conclusion}

The significant interaction between dietary Leu and Val level in the present study resulted in impaired performance and integrity of the tibia and jejunum parameters at the low level of dietary Leu, which could be alleviated by increasing Val levels, but such positive effects could not be completely accomplished at higher Leu level. Attention should be given to balancing Leu and Val levels to account for proper gut and bone development, especially in low-protein diets. More studies are suggested to evaluate the requirements of dietary Leu and Val levels for bone and intestinal development of broilers of all ages. Gly-Glu supplementation in low-CP broiler diets seemed to further improve FCR, but the mechanism related to gut development and the relationship with Val must be further investigated.

\section{Acknowledgments}

This work was supported by grants from Evonik Nutrition \& Care $\mathrm{GmbH}$, Germany and is the part of the PhD thesis of Sh. Golzar Adabi at the Department of Animal Science, Faculty of Agriculture, Ankara University.

\section{Authors' Contributions}

NC and IÇ designed the trial. SHGA submitted the ethics clearance application. SHGA executed the trial and run laboratory analyses. SHGA and AC performed collection of the intestine samples, histological analyses, and interpretation of results. SHGA and NC run the statistical analyses, interpreted the results, wrote the draft paper. All authors checked the results and contributed to preparing the manuscript and agreed on the final version.

\section{Conflict of Interest Declaration}

There are no conflicts of interest.

\section{References}

Aftab, U., Ashraf, M. \& Jigang, Z., 2006. Low protein diets for broilers. World's Poult. Sci. J. 62, 688-701.

AOAC, 2006. Association of Official Analytical Chemists. Official methods of analysis. 15th edition. Washington, DC.

Berres, J., Vieira, S.L., Dozier III, W.A., Cortes, M.E.M., de Barros, R., Nogueira, E.T. \& Kutschenko, M., 2010. Broiler responses to reduced-protein diets supplemented with valine, isoleucine, glycine, and glutamic acid. J. Appl. Poult. Res. 19, 68-79. Doi: 10.3382/japr.2009-00085

Brosnan, J.T. \& Brosnan, M.E., 2006. Branched-chain amino acids: Enzyme and substrate regulation. J. Nutr.136, 207211. Doi: 10.1093/jn/136.1.207S 
Burnham, D., Emmans, G.C. \& Gous, R.M., 1992. Isoleucine requirement of the chicken: The effect of excess leucine and valine on the response to isoleucine. Br. Poult. Sci. 33, 71-87. Doi: 10.1080/00071669208417445

Bush, J.A., Nguyen, H.V., Suryawan, A., O'Connor, P.M.J., Burrin, D.G., Reeds, P.J., Liu, C.W. \& Davis, T.A., 2001. Tissue-specific response of protein metabolism to somatotropin treatment in growing pigs. FASEB J. 15 (Abstr.): A730.

Corzo, A., Moran Jr, E.T. \& Hoehler, D., 2004. Valine needs of male broilers from 42 to 56 days of age. Poult. Sci. 83, 946-951. Doi: 10.1093/ps/83.6.949

Corzo, A.C., Fritts, A., Kidd, M.T. \& Kerr, B.J., 2005. Response of broiler chicks to essential and non-essential amino acid supplementation of low crude protein diets. Anim. Feed Sci. Tech. 118, 319-327. Doi: https://doi.org/10.1016/j.anifeedsci.2004.11.007

Corzo, A., Loar, R.E. \& Kidd, M.T., 2009. Limitations of dietary isoleucine and valine in broiler chick diets. Poult. Sci. 88, 1934-1938. Doi: 10.3382/ps.2009-00109

Corzo, A., Loar, R.E., Kidd, M.T. \& Burges, S.C., 2011. Dietary protein effects on growth performance, carcass traits and expression of selected jejunal peptide and amino acid transporters in broiler chickens. Br. Poult. Sci. 13, 139-146. Doi: http://dx.doi.org/10.1590/S1516-635X2011000200008

Dean, D.W., Bidner, T.D. \& Southern, L.L., 2006. Glycine supplementation to low protein, amino acid-supplemented diets supports optimal performance of broiler chicks. Poult. Sci. 85, 288-296. Doi: 10.1093/ps/85.2.288

D'Mello, J.P.F., 1975. Amino acid requirements of the young turkey: Leucine, isoleucine and valine. Br. Poult. Sci. 16, 607-615. Doi: 10.1080/00071667508416236

D'Mello, J.P.F. \& Lewis, D., 1970a. Amino acid interactions in chick nutrition. 2. The interrelationship between leucine, isoleucine, and valine. Br. Poult. Sci. 11, 313-323. Doi: 10.1080/00071667008415821

D'Mello, J.P.F. \& Lewis, D., 1970b. Amino acid interactions in chick nutrition. 3. Interdependence in amino acid requirements. Br. Poult. Sci. 11, 367-385. Doi: 10.1080/00071667008415827

Evonik, 2010. Aminodat 4.0. Redshaw, M.S., J. Fickler, J. Fontaine, W. Heimbeck, V. Hess, and I. Reinmann. Evonik Industries, Evonik Degussa GmbH, HanauWolfgang, Germany.

Farran, M.T., Barbour, E.K. \& Ashkarian, V.M., 2003. Effect of excess leucine in low protein diet on ketosis in 3-week-old male broiler chicks fed different levels of isoleucine and valine. Anim. Feed Sci. Technol. 103, 171-176. Doi: https://doi.org/10.1016/S0377-8401(02)00289-4

Farran, M.T. \& Thomas, O.P., 1992a. Valine deficiency. 1. The effect of feeding a valine- deficient diet during the starter period on performance and feather structure of male broiler chicks. Poult. Sci. 71, 1879-1884. Doi: 10.3382/ps.0711879

Farran, M.T. \& Thomas, O.P., 1992b. Valine deficiency. 2. The effect of feeding a valine- deficient diet during the starter period on performance and leg abnormality of male broiler chicks. Poult. Sci. 71, 1885-1890. Doi: 10.3382/ps.0711885

Foroudi, F. \& Rezamand, P., 2014. The effects of dietary valine on performance, serum antibody titre and bone mineralization in broiler chicks. Iran. J. Appl. Anim. Sci. 4, 405-409.

Gheorghe A., Dragotoiu, D., Ciurescu, G., Lefter, N. \& Habeanu, M., 2013. Effects of dietary protein level on protein deposition in broilers: 2 . body composition, plasma metabolic profile and litter composition. Bul. UASVM Anim. Sci. Biotechnol. 70, 274-283. http://dx.doi.org/10.15835/buasvmcn-asb:70:2:9303

Harper, A.E., Miller, R.H. \& Block, K.P., 1984. Branched-chain amino acid metabolism. Annu. Rev. Nutr. 4, 409-454. Doi: DOI: 10.1146/annurev.nu.04.070184.002205

Hempe, J.M., Lauxen, R.C. \& Savage, J.E., 1988. Rapid determination of egg weight and specific gravity using a computerized data collection system. Poult. Sci. 67, 902-907. Doi: 10.3382/ps.0670902

Hevia, P. \& Clifford, J., 1977. Protein intake, uric acid metabolism and protein efficiency ratio in growing chicks. J. Nutr. 107, 959-964. Doi: 10.1093/jn/107.6.959

Kidd, M.T., Kerr, B.J., Firman, J.D. \& Boling, S.D., 1996. Growth and carcass characteristics of broilers fed low-protein threonine-supplemented diets. J. Appl. Poult. Res. 5, 180-190. Doi: https://doi.org/10.1093/japr/5.2.180

Leresche, R.E., Seal, U.S., Karns, P.D. \& Franzmann, A.W., 1974. A review of blood chemistry of moose and other cervidae with emphasis on nutritional assessment. Nat. Can. 101, 263-290.

Leveille, G.A. \& Sauberlich, H.E., 1961. Influence of dietary protein level on serum protein components and cholesterol in the growing chick. J. Nutr. 74, 500-504. Doi: https://doi.org/10.1093/jn/74.4.500

Liames, C.R. \& Fontaine, J., 1994. Determination of amino acids in feeds: Collaborative study. J. AOAC Int. 77, 13621402.

McGill, E.R., 2009. Effects of low crude protein diets with amino acid supplementation on broiler performance in the starter period. Master of Science Diss. Univ. Missouri-Columbia.

Namroud, N.F., Shivazad, M. \& Zaghari, M., 2008. Effects of fortifying low crude protein diet with crystalline amino acids on performance, blood ammonia level, and excreta characteristics of broiler chicks. Poult. Sci. 87, $2250-2258$. Doi: $10.3382 / p s .2007-00499$

Onyango, E.M., Hester, P.Y., Stroshine, R. \& Adeola, O., 2003. Bone densitometry as an indicator of percentage tibia ash in broiler chicks fed varying dietary calcium and phosphorus levels. Poult. Sci. 82, 1787-1791. Doi: 10.1093/ps/82.11.1787

Ospina-Rojas, I.C., Murakami, A.E., Duarte, C.R.A., Nascimento, G.R., Garcia, E.R.M., Sakamoto, M.I. \& Nunes, R.V., 2017. Leucine and valine supplementation of low-protein diets for broiler chickens from 21 to 42 days of age. Poult. Sci. 96(4), 914-922. Doi: 10.3382/ps/pew319 
Reeds, P.J., Burrin, D.G., Stoll, B., Jahoor, F., Wykes, L., Henry, J. \& Frazer, M.E., 1997. Enteral glutamate is the preferential source for mucosal glutathione synthesis in fed piglets. Am. J. Physiol. 273, $408-415$. Doi:10.1152/ajpendo.1997.273.2.E408

Ren, M., S.H. Zhang, X.F. Zeng, Liu, H. \& Qiao, S.Y., 2015. Branched-chain amino acids are beneficial to maintain growth performance and intestinal immune-related function in weaned piglets fed protein restricted diet. AsianAustralas. J. Anim. Sci. 28, 1742-1750. Doi: 10.5713/ajas.14.0131

Richards, J.D., Atwell, C.A., Vasquez-Anon, M. \& Dibner, J.J., 2005. Comparative in vitro and in vivo absorption of 2hydroxy-4(methylthio)butanoic acid and methionine in the broiler chicken. Poult. Sci. 84, 1397-1405. Doi: 10.1093/ps/84.9.1397

Ritchie, B.W., Harrison, G.J. \& Harrison, L.R., 1994. Avian medicine: Principles and application. Wingers, Florida, 1341.

Scholtz, N., Halle, I., Flachowsky, G. \& Sauerwein, H., 2009. Serum chemistry reference values in adult Japanese quail (Coturnix coturnix japonica) including sex-related differences. Poult. Sci. 88, 1186-1190. Doi: 10.3382/ps.200800546

Sedlak, T.W. \& Snyder, S.H., 2004. Bilirubin benefits: Cellular protection by a biliverdin reductase antioxidant cycle. Pediatrics 113, 1776-1782. Doi: 10.1542/peds.113.6.1776

Silk, D.B., Grimble, G.K. \& Rees, R.G., 1985. Protein digestion and amino acid and peptide absorption. Proc. Nutr. Soc. 44, 63-72. Doi: 10.1079/PNS19850011

Sklan, D. \& Plavnik, I., 2002. Interactions between dietary crude protein and essential amino acid intake on performance in broilers. Br. Poult. Sci. 43, 442-449. Doi: 10.1080/00071660120103710

Solis de los Santos, F., Tellez, G., Farnell, M.B., Balog, J.M., Anthony, N.B., Pavlidis, H.O. \& Donoghue, A.M., 2005. Hypobaric hypoxia in ascites resistant and susceptible broiler enetic lines influences gut morphology. Poult. Sci. 84, 1495-1498. Doi: 10.1093/ps/84.9.1495

Straková, E., Suchý, P., Herzig, I., Steinhauser, L., Šerman, V. \& Mas, N., 2009. Amino acid profile of protein from pelvic limb long bones of broiler chickens. Acta Vet. 78, 571-577. Doi: https://doi.org/10.2754/avb200978040571

Stoll, B., Henry, J., Reeds, P.J., Yu, H., Jahoor, F. \& Burrin, D.G., 1998. Catabolism dominates the first-pass intestinal metabolism of dietart essential amino acids in milk protein-fed piglets. J. Nutr. 128, 606-614. Doi: 10.1093/jn/128.3.606

Suvarna, K.S., Layton, C. \& Bancroft, J.D., 2012. Bancroft's theory and practice of histological techniques. 7th ed. Churchill Livingstone, London.

Szabo A., Mezes, M., Horn, P., Suto, Z., Bazar, G.Y. \& Romvari, R., 2005. Developmental dynamics of some blood biochemical parameters in the growing turkey (Meleagris gallopavo). Acta Vet. Hung. 53, 397-409. Doi: 10.1556/AVet.53.2005.4.1

Tavernari, F.C., Lelis, G.R., Vieira, R.A., Rostagno, H.S., Albino, L.F.T. \& Oliveira Neto, A.R., 2013. Valine needs in starting and growing Cobb (500) broilers. Poult. Sci. 92, 151-157. Doi: 10.3382/ps.2012-02278

Van der Schoor, S.R.D., van Goudoever, J.B., Stoll, B., Henry, J.H., Rosenberger, J., Burrin, D.B. \& Reeds, P.J., 2001. The pattern of intestinal substrate oxidation is altered by protein restriction in pigs. Gastroenterology. 121, 671175. Doi: 10.1053/gast.2001.29334

Van Nevel, C.J., Decuypere, J.A., Dieric, N.A. \& Moll, K., 2005. Incorporation of galactomannans in the diet of newly weaned piglets: Effect on bacteriological and some morphological characteristics of the small intestine. Arch. Anim. Nutr. 59, 123-138. Doi: 10.1080/17450390512331387936

Willems O.W., Miller, S.P. \& Wood, B.J., 2013. Aspects of selection for feed efficiency in meat producing poultry. World Poultry Sci. J. 69, 77-88. Doi: 10.1017/S004393391300007X

Wills, E.D., 1985. Biochemical basis of medicine. John Wright \& Sons, Bristol, England. Doi: https://doi.org/10.1016/C2013-0-06466-3

Wu, G., 1998. Recent advances in nutritional science. J. Nutr. 128, 1249-1252. Doi: 10.4172/2155-9600.1000734

Wu, G., 2013. Amino acids: Biochemistry and nutrition. CRC Press, Boca Raton. Doi: 10.1201/b14661

Xu, Z.R., Hu, C.H., Xia, M.S., Zhan, X.A. \& Wang, M.Q., 2003. Effects of dietary fructooligosaccharide on digestive enzyme activities, intestinal microflora and morphology of male broilers. Poult. Sci. 82, 1030-1036. Doi: 10.1093/ps/82.6.1030 